\title{
Lumen
}

Selected Proceedings from the Canadian Society for Eighteenth-Century Studies

\section{'Clubbability’: A Revolution in London Sociability?}

\section{Valérie Capdeville}

Volume 35, 2016

URI : https://id.erudit.org/iderudit/1035921ar

DOI : https://doi.org/10.7202/1035921ar

Aller au sommaire du numéro

Éditeur(s)

Canadian Society for Eighteenth-Century Studies / Société canadienne d'étude du dix-huitième siècle

ISSN

1209-3696 (imprimé)

1927-8284 (numérique)

Découvrir la revue

Citer cet article

Capdeville, V. (2016). ‘Clubbability': A Revolution in London Sociability? Lumen,

35, 63-80. https://doi.org/10.7202/1035921ar d'utilisation que vous pouvez consulter en ligne.

https://apropos.erudit.org/fr/usagers/politique-dutilisation/ 


\title{
'Clubbability': A Revolution in London Sociability?
}

\author{
Valérie Capdeville
}

Université Paris 13

An anecdote recorded by James Boswell on November $29^{\text {th }}, 1783$ revealed the first occurrence of the word 'clubable' coined by Samuel Johnson: "I was in Scotland when this Club was founded during all the winter. Johnson, however, declared I should be a member, and invented a word upon the occasion: 'Boswell (said he) is a very clubable man.' When I came to town I was proposed to Mr Barrington, and chosen." Johnson considered Boswell as "the best travelling companion in the world" and, according to him, his liveliness and good nature, his passion for good company and friendship, his sympathy and amiability made him acceptable everywhere. The Oxford English Dictionary defines the adjective 'clubable' or 'clubbable' as "fit to be a member of a social club, sociable." Yet, 'clubbable' is frequently used as a synonym for 'sociable' although being clubbable implies something far more specific than being sociable. 'Clubbability' is a quality or attribute which is intrinsically linked to the emergence and success of gentlemen's clubs in the eighteenth century and, as such, corresponds to a significant shift, a 'revolution' in meaning and social practices. ${ }^{2}$ If a 'revolution' in sociability involves the combination of

1. James Boswell, Life of Johnson, ed. by R.W. Chapman, 1953 (Oxford: OUP, 1998), 1260.

2. While James Farr insisted on the protean and mutable character of the term 'revolution' and chose it to demonstrate the evolution of historical concepts, JeanPierre Bardet's aim was to explain how, from its original use either in astronomy or as a political concept referring to a violent reversal or overthrow of a social and political order, 'revolution' has experienced a linguistic extension which has enabled 
various political, social and cultural factors, the development of club life in London played a crucial role in the evolution and transformation of social interactions and forms of sociability in the course of the eighteenth century.

The aim of this paper is to define and explore the concept of 'clubbability' originating from the eighteenth-century London club and to show to what extent this concept can be considered a unique phenomenon in the history of British sociability. The emergence of the club as a new institution from the Restoration period into the eighteenth century will serve as a starting point. Then, identifying the linguistic and cultural shift between 'sociable' and 'clubbable' will enable us to demonstrate that the sense of exclusive belonging inherent to 'clubbability' makes it at the same time a paradoxical concept and a revolutionary phenomenon in London sociability.

Starting by tracing the use of the word 'clubbability' not only in historical sources but by simply typing it in several search engines proves very telling. One is first confronted with the unstable spelling of the word itself, with either one or two b's. Most results come with two b's. One of the first hits is a website called www.clubbability. com. This "new global online magazine" aims to promote "the joys of membership in a private social club to a new younger generation." While this British website intends to highlight the attractive features of various clubs, it also endeavours to maintain the mystique and mystery of private clubs thanks to different posts on topics that are more or less related to club life and may seem stereotypically masculine:

historians to associate it with major cultural and social changes, mutations and innovations. Hence, such concepts as 'consumer revolution,' 'scientific revolution' or 'revolution of mentalities' do not necessarily imply a sudden change or disruption of an existing order, but refer to more complex and progressive mechanisms, to decisive and irreversible transformations. James Farr, "Historical Concepts in Political Science: The Case of 'Revolution," American Journal of Political Science 26: 4 (Nov. 1982), 688-708; Jean-Pierre Bardet, "Autour du concept de révolution: jeux de mots et reflets culturels," Histoire, Economie et Société 10: 1 (1991), 7-16. See also a more recent analysis by D.N. Dhanagar, "From Ideal Type to Metaphor: Rethinking the Concept of 'Revolution," Sociological Bulletin 61: 1 (January-April 2012), 53-88.

3. http://www.clubbability.com/?page_id=2 ('Introduction to clubbability'). 
prestige cars, fine cigars and wines, exclusive dining or sports clubs in England and abroad. Another significant hit enables us to find the only academic paper which contains the word 'clubbability' in its title. Published in the Journal of British Studies in 2001 by Mrinalini Sinha, entitled "Britishness, Clubbability, and the Colonial Public Sphere: the Genealogy of an Imperial Institution in Colonial India," this very interesting study analyses the role of clubs in promoting British values in colonial India, thus fashioning a 'British white identity' in the nineteenth century. It also demonstrates the influence of 'clubbability' in the constitution of a distinctive 'colonial public sphere.' Moreover, a chapter on 'Social Prestige and Clubbability,' in a book by Philip Waller, Writers, Readers, and Reputations: Literary Life in Britain, 1870-1918, describes how "membership of West End clubs was valued as a mark of intellectual and social advancement." 5

The literature on clubs is vast, full of anecdotes and descriptive accounts, but very few studies have attempted to analyse their emergence, their evolution, and to understand the characteristics and paradoxes of this emblematic British institution. In a $1980 \mathrm{PhD}$ dissertation devoted to the working men's club movement by the end of the Victorian era, ${ }^{6}$ Laurence Marlow chose to entitle his first chapter "Clubbable Englishmen: the development and ideology of the club in British society." In a rich introductory panorama of the expansion of gentlemen's clubs, he pointed at the intrinsic link between 'clubbability' and club life and identified the notion as a social phenomenon. However, 'clubbability' both as a specific individual or collective attribute and as a unique linguistic term remained unexplored. Although eighteenth-century historian Paul Langford entitled a section of his book Englishness Identified 'Clubbability,'? his main focus, though, was the conversational nature of both Parliament and gentleman's clubs

4. Mrinalini Sinha, "Britishness, Clubbability, and the Colonial Public Sphere: the Genealogy of an Imperial Institution in Colonial India," Journal of British Studies 40: 4 (Oct. 2001), 489-521.

5. Philip J. Waller, Writers, Readers, and Reputations: Literary Life in Britain, 1870-1918. (Oxford; New York: OUP, 2006), 490.

6. Laurence Marlow, “The working men's club movement, 1862-1912: a study of the evolution of a working class institution." Unpublished PhD diss. (University of Warwick, 1980), 21-120.

7. Paul Langford, Englishness Identified. Manners and Character, 1650-1850 (Oxford: OUP, 2000), 213. 
supported by the analogy established by the Italian traveller Alessandro Verri on his visit to London in $1767 .{ }^{8}$ Unfortunately, the historian fails to pin down the meaning of the word. In fact, 'clubbability' definitely refines and complicates the concept of 'sociability' relating it to national character as well as to cultural and social transformations at stake in the eighteenth century.

Peter Clark's seminal work British Clubs and Societies, 1580-180o: the Origins of an Associational World (2000), after his 1986 lecture at Leicester University, has focused on the progressive development of urban club life and has offered a new analytical entry into the constitution of a national political community in order to identify the cultural, political and social character of British associational culture. ${ }^{9}$ In previous work, I argued that the London club represented a unique form of sociability, an institution whose paradoxes reflected its quintessentially English character. ${ }^{10}$ Considering the significant influence this model of sociability has had on the evolution of British sociability as a whole over the course of the eighteenth century, and the lack of specific scholarly attention on the concept of 'clubbability' itself, I argue here that this very notion deserves to be explored and re-contextualized.

What do the internet search and this quick historiographical survey reveal about the concept of 'clubbability' in relation to eighteenthcentury sociability? First, they show that it is almost always associated with the Victorian and Edwardian periods, since it only became identified with club sociability at that time, thus half a century after Samuel Johnson's inventive coinage of the word 'clubable' in 1783 . Therefore, this periodization shifts the heyday of clubs to a later period, ignoring the birth of the club in the Restoration and its rapid development over the course of the eighteenth century, reaching its golden age

8. Pietro \& Alessandro Verri, Viaggio a Parigi e Londra (1766-67), ed. by Gianmarco Gaspari (Milano: Adelphi, 1980).

9. Peter Clark, British Clubs and Societies, 1580-180o: the Origins of an Associational World (Oxford: Clarendon Press, 2000) and Sociability and Urbanity: Clubs and Societies in the Eighteenth-Century City (Leicester: University of Leicester Press, 1986).

10. Valérie Capdeville, L'Age d'or des clubs londoniens (1730-1784) (Paris: H. Champion, 2008); "London clubs or the invention of a home-made sociability" in Valérie Capdeville \& Eric Francalanza (eds.) La Sociabilité en France et en GrandeBretagne au siècle des Lumières: L'émergence d'un nouveau modèle de société. Tome 3: Les Espaces de sociabilité (Paris: Le Manuscrit, coll. 'Transversales,' 2014), 75-100. 
in Johnson's days when being a clubman had already become a way of life. Second, it appears as a purely British concept, with no lexical equivalent in any language, a national cultural practice that became strong enough to be exported to the British colonial Empire. ${ }^{11}$

\section{The club: a new social institution}

Eighteenth-century London was characterized by a 'revolution' in sociability, through the emergence of distinctive sociable spaces as well as the evolution of sociability practices. Social life in the English capital experienced important new developments as a consequence of cultural, political and social changes at work through the Restoration period and especially after the Glorious Revolution. ${ }^{12}$ The explosion of the press favoured by the end of censorship in 1695, the birth of public opinion and of political parties with the emergence of a new public sphere, the rise of the merchant class thanks to the expansion of trade as well as the advent of conspicuous consumption and leisure, were all significant factors of change in urban sociability, as they promoted sociable interaction between individuals. The second half of the seventeenth century can be considered as a prequel to the emergence of new social practices. Phil Withington's work on the concepts of 'society' and 'company' in early modern England has shed light on the modern concept of sociability. ${ }^{13}$ In the seventeenth century, the term 'company' was used to describe institutionalized as well as non-institutionalized organisations, formal or less formal associational bodies or communities. Yet, it already suggested "a politics (in the broad sense

11. While the club is originally an English institution and has been associated with the English character, the concept of 'clubbability' can be considered as British in its full sense. Indeed, the club model was diffused to Scotland and Ireland and club sociability was also exported to the American colonies as early as the 1720 and to most British colonies around the globe. On clubs' overseas expansion, see Clark, British Clubs and Societies, 388-420.

12. In 1777, Gabriel Bonnot de Mably affirmed: "il n'arrive jamais de révolution subite parce que nous ne changeons point en un jour notre manière de voir, de sentir et de penser. Si un peuple paraît changer brusquement de mœurs, de génie et de loix, soyez sûr... que cette révolution a été préparée pendant longtemps par une longue suite d'événements et par une longue fermentation des passions." Gabriel Bonnot de Mably, De l'étude de l'histoire (1777), quoted by Alain Rey, "Révolution," Histoire d'un mot (Paris: Gallimard, 1989), 88.

13. Phil Withington, "Company and Sociability in Early Modern England," Social History 32: 3 (Aug. 2007), 291-307. 
of the term) of social participation involving inclusions, exclusions and the construction of boundaries." 14

London clubs first appeared as rather informal assemblies of men which met in public places such as coffee houses and taverns in the second half of the seventeenth century and flourished in the eighteenth century as increasingly exclusive and private institutions. In 1659, John Aubrey noted, "We now use the word clubbe for a sodality [a society, association, or fraternity of any kind] in a tavern." The first significant 'clubs' were the Rota, ${ }^{15}$ whose republican members gathered at the Turk's Head Coffee-House as early as 1659 (also called the 'Coffee-club' par Samuel Pepys), or the Green Ribbon Club, whose Whig members met at the King's Head Tavern from 1674. As new spaces for political discussion and a new way of diffusing political ideas and influencing public opinion, they proved useful tools of both opposition propaganda and party organisation. ${ }^{16}$ The early decades of the eighteenth century saw the multiplication of clubs, such as the famous Kit Cat Club which, apart from its Whig affiliation, can be considered as one of the first prominent social and literary clubs of the capital. Needless to say, the fictional club invented in 1711 by Joseph Addison in the Spectator contributed to an increasing popularity of the institution and, through the promotion of the gentleman ideal, shaped the future conception of Johnson's 'clubbable man.'

In the first half of the eighteenth century, the term 'club' referred to any association or society in which men gathered with a common aim and met on a regular basis in a precise location according to certain rules, in order to maintain social relationship and a spirit of cooperation. Indeed, the development of the club answered new

14. Withington, 301

15. Quoted in John Timbs, Club life of London with Anecdotes of the clubs, coffeehouses and taverns of the metropolis during the $17^{\text {th }}, 18^{\text {th }}$ and $19^{\text {th }}$ centuries, vol. 1 (London: Richard Bentley, 1866), 4. The name Rota comes from one of its founding principles, which is the club's main project: one third of the members of Parliament would retire each year, in rotation, so that in three years, a complete renewal would be made.

16. "to make Proselytes, especially of the raw estated Youth newly come to town," Roger North, Examen or, an Enquiry into the Credit and Veracity of a Pretended Complete History (London: 1740), 572. The Green Ribbon Club occupied an important place on the political scene: during the Exclusion Crisis, it played a crucial part in the Whig propaganda campaign. It was considered as 'a sort of executive power' for the opponents of the Court. 
aspirations in a changing urban environment. Eager to be informed, to exchange ideas, to conduct business or simply to frequent good company, men gathered to read and share the latest news, to discuss literary matters and participate in political debates, to enjoy their favourite pastimes in a convivial atmosphere. Addison acknowledged this cohesive dimension of the club in his Spectator: "Men are thus knit together, by a Love of Society, [...] combined for their own improvement, or for the Good of others, or at least to relax themselves from the Business of the Day, by an innocent and cheerful Conversation, there may be something very useful in these little Institutions and Establishments..."17

From the 1730s, the functioning of club life started to change, as most clubs adopted more selective election procedures and stricter internal regulations. This came from a desire to restrain their access, as a reaction to the openness and publicity of coffee-house sociability. For example, White's Chocolate-House became a private club in 1736 , The Club of Royal Philosophers (future Royal Society Club) appeared in 1731, and the Society of Dilettantti was founded in 1734. Whereas Johnson's definition of the club in 1755 as "an assembly of good fellows, meeting under certain conditions" remained rather vague, ${ }^{18}$ the 1760 s marked another turning point when some clubs such as Brooks's or Boodle's settled in their own larger buildings, therefore both physically displaying a certain aspiration to more privacy, exclusivity and prestige and geographically inscribing themselves in what has been called the London 'clubland.'

\section{From 'sociable' to 'clubbable': a significant shift}

Man's gregarious instinct and his desire to gather into clubs and societies can be explained by his social nature. David Hume, himself a reputed member of Johnson's club, was convinced of man's sociable drive: "The propensity to company and society is strong in all rational creatures." ${ }^{\prime 19}$ As an instrument of socialization, the club provided man

17. Joseph Addison, The Spectator, $\mathrm{n}^{\circ} 9$ (March 10, 1711).

18. Samuel Johnson, Dictionary of the English Language, 1755 (4th edition, revised, 1773), vol. 1.

19. David Hume, "Of National Characters," Selected Essays (Oxford: World's Classics, OUP, 1993), 115 . 
with social interaction and convivial exchange. Addison justified the formation of clubs as a sign of man's social ability or sociability: "Man is said to be a Sociable Animal, and, as an Instance of it, we may observe, that we take all Occasions and Pretences of forming ourselves into those little Nocturnal Assemblies, which are commonly known by the name of "Clubs." 20

Although 'sociable' has a transparent equivalent in French, 'sociable' and an exact translation in German 'gesellig,' there is no equivalent to Johnson's term in French or in German. The word 'salonfähig' has frequently been used in German as a synonym to 'clubbable,' but it only means in fact 'socially acceptable,' in French 'convenable ou presentable en société, thus failing to convey the true meaning of the English word. Clubbability remains a specific type of sociability, which is rooted in a historical and cultural national reality, both as a way of interacting with others and as an individual quality in a definite social context, that of the English club. Therefore, 'clubbability' should not be taken as an exact equivalent to 'sociability,' since the concept encapsulates the very essence of the club phenomenon in a national context. Here, we may add that while the English club model also flourished in Scotland, Ireland and in most British colonies, the adjective 'clubbable' followed the diffusion or expansion of clubs outside England. When some clubs preserved their most significant features, others adapted to different local contexts. ${ }^{21}$

However, as the definition of a club itself evolved, the concept of 'clubbability' started to symbolize a specific attribute of Britishness only in the nineteenth century: "an association of persons (admittance into which is usually guarded by ballot), formed mainly for social purposes and having a building (or part of one) appointed to the exclusive use of the members." ${ }^{22}$ More than referring to the sociable qualities of an individual, his polite manners and friendly skills - such as conviviality, amiability, sympathy - clubbability also specifically outlined his ability

20. Addison, The Spectator, $n^{\circ} 9$.

21. For example, Corey Andrews insisted on the role of the Tarbolton Bachelors Club (founded by Robert Burns in November 1780) in the self-formation of the poet's personality as well as in the construction of a Scottish national character, in 'The Clubbable Bard: Sentimental Scottish Nationalism and Robert Burns,' Lumen XXI (2002), 105-30.

22. See The Compact Edition of the Oxford English Dictionary, vol. 1 (1933; reprint, New York, 1977), 534. 
to be accepted and esteemed in any select and closed circle. It can be argued that already in the eighteenth century, 'clubbability' not only defined the ability of men to club together but also how suited they were to club membership.

A clubman's education comprised the acquisition of learning (referring to the knowledge gained through schooling and mainly book study), but also politeness through conversation and sociability. These were essential steps to become an accomplished gentleman and to be recognized as such by one's peers. Boswell remembers that: "When Mr. Vesey was proposed as a member of The Literary Club, Mr. Burke began by saying that he was a man of gentle manners. 'Sir, (said Johnson,) you need say no more. When you have said a man of gentle manners; you have said enough." 23 For the English gentleman, the club served as an instrument of self and social construction, shaping his character both as a private individual and as a public man. The combination of knowledge and good breeding was also dear to Lord Chesterfield when advising his son: "knowledge will introduce him, and good breeding will endear him to the best companies; for, as I have often told you, politeness and good breeding are absolutely necessary to adorn any or all other good qualities or talents." 24 Samuel Johnson, described by Boswell as "socially accommodating," cherished club life and felt a sense of personal fulfilment and happiness through the love of company, the spirit of friendship and the masculine conviviality promoted by the club. He considered the club as the perfect means for a gentleman to acquire and refine his education, politeness, conversation, worldly experience and to build a literary, business or political career. As Roy Porter stated, "in their role as self-appointed custodians of culture, literary clubs combined some of the functions of the Paris salon and the university the capital lacked." ${ }^{26}$

The ideal of the gentleman through politeness and refined conversation, which prevailed among the exclusive circles of London society,

23. Boswell, 1085 .

24. Philip Dormer Stanhope (Lord Chesterfield), Letter XCVI (Oct. 9, 1747), Letters written by the late right honourable Philip Dormer Stanhope ... to his son, Philip Stanhope: Together with several other pieces on various subjects, 4 vols. (6 $6^{\text {th }} \mathrm{ed}$.), (London: J. Dodsley, 1775), 1: 281.

25. Boswell, 338 .

26. Roy Porter, “The Need for buddies," review of Peter Clarks's British Clubs and Societies, in the London Review of Books 22: 12 (22 June 2000), 30-31. 
corresponded to a desire to shape a new model of masculinity. ${ }^{27}$ Club sociability and conversation were simply thought inappropriate for the female sex. Indeed, clubs played a significant role in preserving the image and life of the gentleman. From the public school to the university then to the club, the continuity of the gentleman's self-construction was a central process. In promoting gentlemanly behaviour and in defining norms of masculinity, these male-only institutions provided "a social space where sections of the aristocracy and the upper middle class could join together." 28

\section{A sense of exclusive belonging}

The club provided young men not only with a space devoted to social relations, but also with a group to belong to. The election of a new member was frequently followed by an initiation ritual which, as a shared experience, both produced a sense of belonging to a selective community as well as strengthened clubmen's ties. ${ }^{29}$ Its definite norms and rules reflected its exclusive nature and were constitutive elements in the identity of this institution, half-way between the private and public spheres. ${ }^{30}$

In the second half of the century, foreign travellers, such as PierreJean Grosley, underlined the socializing yet selective power of clubs: "ces coteries remplissent [...] tout le besoin qu'a l'homme de la société de ses semblables." 31 Socializing among 'equals' became a major feature of London clubs, with the promotion of a more selective sociability reserved to a limited number of individuals. Living among equals was a perfect way to answer this need for distinction, community of

27. Valérie Capdeville, "Gender at stake: the role of eighteenth-century London clubs in shaping a new model of English masculinity," Culture, Society 6 Masculinities 4: 1 (Spring 2012), 13-32.

28. Marlow, 107.

29. Capdeville, L'Age d'or des clubs londoniens (1730-1784), 241-42.

30. For an analysis of the special status of the club in the private/public sphere dialectics and its identification as a 'social space' and a 'space-between,' see Michèle Cohen, "Manliness, Effeminacy and the French: Gender and the Construction of National Character in Eighteenth-Century England," in M. Cohen \& T. Hitchcock, English Masculinities. 1660-180o (London \& NY: Longman, 1999), 47, and Capdeville's introduction to Les Espaces de sociabilité, 31.

31. Pierre-Jean Grosley, Londres: Ouvrage d'un Français, 3 vols. (Neuchâtel: aux dépens de la Société Typographique, 1774), 1: 212. 
values and education, so central to the social and governing elites. As clubbability implied a community of values, education, rank and a constant desire to gather among distinguished equals, it inevitably led most clubs to favour a form of social elitism. Indeed, as Amy MilneSmith justly puts it in her recent analysis of Victorian clubs, the clubland we mentioned earlier was "not only a space on the map, but also a defined community of elite men." 32

For Johnson's Club, founded in 1764 , the number of its members was strictly limited and, composed of the intellectual elite of the time, a real "aristocracy of the mind." ${ }^{33}$ Boswell remembered:

Soon after his return to London, which was in February, was founded that CLUB which existed long without a name, but at Mr. Garrick's funeral became distinguished by the title of THE LITERARY CLUB. Sir Joshua Reynolds had the merit of being the first proposer of it, to which Johnson acceded, and the original members were, Sir Joshua Reynolds, Dr. Johnson, Mr. Edmund Burke, Dr. Nugent, Mr. Beauclerk, Mr. Langton, Dr. Goldsmith, Mr. Chamier, and Sir John Hawkins. They met at the Turk's Head, in Gerrard-street, Soho, one evening in every week, at seven, and generally continued their conversation till a pretty late hour. ${ }^{34}$

Becoming a member of Johnson's Club remained a privilege, reserved to few, an honour that Boswell recalled not without a certain satisfaction:

On Friday, April 30, I dined with him at Mr. Beauclerk's, where were Lord Charlemont, Sir Joshua Reynolds, and some more members of the LITERARY CLUB, whom he had obligingly invited to meet me, as I was this evening to be balloted for as candidate for admission into that's distinguished society. Johnson had done me the honour to propose me, and Beauclerk was very zealous for me. ${ }^{35}$

After his election at the Club, Boswell related: "Upon my entrance, Johnson placed himself behind a chair, on which he leaned as on a desk or pulpit, and with humorous formality gave me a Charge, pointing out the conduct expected from me as a good member of this

32. Amy Milne-Smith, London Clubland. A Cultural History of Gender and Class in Late Victorian Britain (New York, Palgrave Macmillan, 2011), 22.

33. Lewis Perry Curtis \& Herman W. Liebert, Esto Perpetua, The Club of Dr Johnson and his Friends. 1764-84 (Hamden: Archon Books, 1963), 5.

34. Boswell, 338-39.

35. Ibid., 527 . 
club." ${ }^{36}$ Significantly enough, Johnson was opposed to the extension of the club and when Oliver Goldsmith told Johnson that he wished the club to welcome additional members "to give it an agreeable variety; for (said he,) there can now be nothing new among us: we have travelled over one another's minds, Johnson seemed a little angry, and said, 'Sir, you have not travelled over MY mind, I promise you." 37

The constant quest for social and political exclusiveness and preeminence led to the creation of networks of power. When Boodle's was founded in 1762 , three quarters of its members were members of Parliament (Lords or Commons) - most of them being friends or associates of Lord Shelburne, ${ }^{38}$ the future Prime Minister. Belonging to Shelburne's entourage, as members of 'his' club, enabled some to boost their political careers. Thanks to their proximity to already renowned politicians, sharing their conversations and pastimes, the younger members of White's and Brooks's would find the doors of parliamentary life widely open and the accession to some governmental functions more easily reached. As suggested earlier, the club as an antechamber of power often resembled a 'miniature parliament.'

Networks of influence were then inevitably taking shape, thanks to multi-membership: Charles James Fox, an eminent member of Brooks's, was also a member of the Society of Dilettanti (1769) and of Johnson's Club (1774). Another example, George A. Selwyn, became a member of White's in 1744, was one of the founding members of Brooks's in 1764 , then became a member of the Society of Dilettanti in 1770. ${ }^{39}$ This fashionable practice contributed to widen the circle of one's acquaintances, making it easier to be elected thanks to good recommendations. In addition, having a father, an uncle or a brother already in the club could prove very valuable: not surprisingly, club membership was often a tradition from one generation to the other. The membership

36. Ibid., 530.

37. Ibid., 1208.

38. William Petty, Earl of Shelburne (1737-1805), $1^{\text {st }}$ Marquess of Lansdowne, a Whig statesman, Prime Minister from 1782 to 1783 .

39. His passion for gambling was his principal motivation to enter Brooks's. Like him, Horace Walpole, a member of White's since 1744, joined Brooks's in 1764. As for Topham Beauclerk, even if his knowledge and his friendship for Johnson had made him an eminent member of The Club since 1764 , he was an inveterate gambler who assiduously frequented Brooks's, of which he became a member the following year, and then also became a member of White's. 
list of White's, for example, testifies to the attachment of some aristocratic families to the institution and vice versa: we find real dynasties of members. ${ }^{40}$ The transmission of clubbability as a social privilege was perfectly described by Horace Walpole who declared, not without humour, that when an heir was born in an aristocratic house, the butler immediately rushed to White's to write his name on the list of candidates then went to the registry office to declare his birth. ${ }^{41}$

\section{'Clubbability': a paradoxical concept}

What becomes obvious when studying 'clubbability' is its paradoxical nature. The function of clubs was clearly not only to favour the integration of their members into the club itself and into the best circles of London society. As contradictory as it may seem, exclusiveness was itself the key to a better social integration. An exclusive membership was a means to guarantee social recognition and to consolidate friendships and networks, but also an instrument of social discrimination as unwelcome candidates were excluded from the group.

In her work on Victorian clubs, entitled A Room of His Own: A Literary-Cultural Study of Victorian Clubland, Barbara Black argues that "a club is an assemblage of insiders, the very identity of which depends upon there being outsiders." She rightly states that the "sameness" that defines a club's members cannot be understood except in contrast to those who are construed as "different," and thus "a club's very existence relies on the imperative of protecting the group from non-members." "That sense of connectedness," she concludes, "provides legitimacy, purpose, and comfort to those who are connected." ${ }^{42}$ This complex and contradictory process reinforces the cohesive power of the club and helps to define English clubbability. As an illustration of that contradiction, Curtis and Liebert, the historians of The Club, reported an anecdote attributed to the Goncourt brothers, ${ }^{43}$ who once

40. Capdeville, L'Age d'or des clubs londoniens, 265.

41. Quoted in W. B. Boulton, The Amusements of Old London, 2 vols. (London: John C. Nimmo, 1901), 2: 195.

42. Barbara Black, A Room of his Own. A Literary-Cultural Study of Victorian Clubland (Athens: Ohio University Press, 2012), 28.

43. Edmond-Louis-Antoine Huot de Goncourt and Jules-Alfred Huot de Goncourt, known as the Goncourt brothers, were nineteenth-century French writers and art critics. 
said that if three Englishmen were cast away on a desert isle, two of them would immediately form a club to keep the third out. ${ }^{44}$ Highlighting the propensity to form a club as a characteristic of the English nation, it somehow parallels Edward Gibbon's description of the Cocoa Tree Club in 1762: "This respectable body, of which I have the honour of being a member, affords every evening a sight truly English." ${ }^{45}$

The inclination to 'club together,' both inclusive and exclusive, was thus considered as inherent to the character of the English nation. ${ }^{46}$ That precise idea also finds a perfect echo in Alexis de Tocqueville's observation:

Je ne comprends pas bien comment l'esprit d'association et l'esprit d'exclusion [...] peuvent exister d'une manière si développée chez le même peuple, et souvent s'y combiner de façon si intime. Exemple, le club: quel plus bel exemple d'association que l'union des individus qui forment un club? Quoi de plus exclusif que l'individu représenté par le club? ${ }^{47}$

The Englishman indeed seems to have the ability to retain his liberty and individuality in company of others, thus satisfying his double aspiration for individuality and society. Indeed, the French politician and romantic author Alphonse Esquiros also noticed: "The Englishman possesses the extreme advantage of remaining himself in the midst of a group of friends and companions, and there is no reason to fear that he will ever sacrifice his liberty for any consideration." ${ }^{48}$ This characteristic paradox of club life has been underlined by Paul Langford, who expressed surprise at the combination of heavy regulations and freedom of that form of sociability. ${ }^{49}$

While clubbability was a crucial attribute of the English gentleman, 'unclubbability,' conversely, could sometimes prove detrimental

44. Anecdote reported in Curtis \& Liebert, 68.

45. Extract from Mr. Gibbon's Journal (24 Nov. 1762) in The Miscellaneous Works of Edward Gibbon (London, 1837), 70.

46. "Only by apprehending both aspects of the institution simultaneously could the personality of the Englishman be understood," Marlow, 111.

47. Alexis de Tocqueville, Voyages en Angleterre et en Irlande de 1835, ed. J-P. Mayer (Paris: NRF Gallimard, 1967), 144.

48. Alphonse Esquiros, The English at home (London: Chapman \& Hall, 1861), $2^{\text {nd }}$ series, 71 .

49. Langford pointed out "their curious ability to imprison themselves within a cumbersome framework of rules and constraints while retaining their apparent freedom of action. A regime of ballots, black balls [...] rule books and so on," (284). 
to his social integration and recognition. Like the university, the club had become a necessary step towards social and political success. Moreover, as man's 'unsocial sociability' was for Immanuel Kant a powerful way to express the conflicting social nature of man, torn between his sociable drive and his individualistic instinct, club life indeed mirrored and somehow reconciled such a paradox. ${ }^{50}$ In that respect, the concept of clubbability distinguishes itself from that of sociability, since it combines the Englishman's aspiration towards individuality, distinction, eccentricity or excess and his appetite for social cohesion, community experience and normative behaviour. Which leads us to the following question: if an unclubbable man can still be sociable, can an unsociable man be clubbable?

The collective identity of the group was enhanced by the capacity of all members to conform to its rules and expectations..$^{51}$ Yet, perfection or conformity did not always prevail among clubmen, as the gentleman ideal often remained, by definition, difficult to reach. The acknowledged liberty, individualism and originality of the Englishman favoured his disregard of some norms of behaviour. Several degrees of dissidence from a normative polite behaviour, supposedly guaranteed by education and sociability, could be observed among clubmen, from excess to deviance and transgression. Reconciling the contradiction of the gentleman ideal, a clubman could drink, gamble, and still remain a gentleman. A combination of virtue and excess as well as a tolerated dissidence from polite norms of behaviour were inherent in the Englishness of the eighteenth-century clubman.

Clubbability could also be seen as a remedy, as a way to curb or at least to soften the unsocial nature of the Englishman. At the beginning of the nineteenth century, the essayist William Hazlitt considered that it was precisely unsociability that explained association: "The English join together to get rid of their sharp points and sense of uncomfortable

50. The 'unsocial sociability' thesis was developed in Immanuel Kant, Idea for a Universal History from a Cosmopolitan Point of View (1784).

51. "Vivre ensemble au sein d'un groupe nécessite un apprentissage, ou plutôt la constitution de repères communs aux membres du groupe. L'intégration au sein d'un club dépend de la compatibilité des dispositions du candidat avec le 'code' de ce groupe, de la capacité du candidat à intégrer, à épouser les exigences qu'on lui présente. Ainsi, la cohésion sera d'autant plus forte que des éléments structurants auront été mis en place, afin de favoriser la construction d'une identité collective," in Capdeville, L'Age d'or des clubs londoniens, 238. 
peculiarity. Hence, their clubs, their mobs, their sects, their parties, their spirit of cooperation..." ${ }^{2}$ Since they were unsociable, they would join clubs and then become clubbable. Clubbability is seen as a taming mechanism to introduce order, to help organize their otherwise unruly lives. Here would lie the power of the club as an instrument of sociability, transforming an unsociable man into a perfect clubman.

After stressing the difference between sociability and clubbability, it is thus easier to understand why some contemporaries denounced exclusiveness itself as a form of unsociability. This antisocial attitude could be explained by "the pressures of commercial growth and social instability [which] had actually transformed the natural character of the English." As Charles Lyell explained in his journal, "being in fact socially disposed, they were obliged to be stiff to strangers, because all were trying to hang upon and be pulled up by the skirts of those above them." 53 In the same way, the exclusion of women from clubs was also seen by some as a symptom of the unsociability of the English nation. As sociability and politeness were the prevailing features of France and were based on feminine refinement and mixed sociability, 'clubbability' appeared as the perfect term to embody England's peculiar sociable identity. The homosocial model of the London club offered a countermodel to the Parisian salon.

Furthermore, clubbability could have a strong effect on political stability and has sometimes been considered as "a great balm for religious and political differences." ${ }^{4}$ By promoting the advancement of knowledge, clubs reduced the likelihood of violent discord. Even the growing political rivalry which opposed White's and Brooks's in the 1780 did not prevent their members from belonging to both clubs: for example, Charles James Fox and his friend and political rival William Pitt were both members of the two. ${ }^{55}$ However, in times of high political tension, animosities between clubs could be reinforced. James

52. The Complete Works of William Hazlitt, ed. by P. P. Howe, 21 vols. (London: J. M. Dent, 1930), 20:178.

53. Life, letters and Journals of Sir Charles Lyell, Bart., 2 vols., ed. by Mrs. Lyell (London, 1881), 2:150.

54. Stephen Miller, Three Deaths and Enlightenment Thought: Hume, Johnson, Marat (Bucknell University Press, 2001), 118.

55. William Pitt was elected at Brooks's in 1781, proposed by his friend of the time, Fox. Then, when he became PM in 1783, he joined White's and also became a member of Boodle's. 
Gillray's caricature, Promis'd Horrors of the French Invasion (1796), depicted Fox in revolutionary dress flogging Pitt as the streets run with blood. The fear that the French revolution would bring political warfare was illustrated by the violent opposition between White's and Brooks's and their leading members. This was, of course, a fictional representation of club life in Britain, which would be contaminated by political rivalries, as Gillray imagined the consequences of France exporting its revolution to Britain. Nevertheless, if political partisanship was reinforced in the nineteenth century with the creation of the Tory Carlton Club (1832) and the Whig Reform Club (1836), clubs were essential to the functioning of democracy, Marlow argued, as they were "central to pluralism because of the political education and socialization they provided." 56

To conclude, I would first answer a question raised by Barbara Black: "Is 'clubable' a quality that clubs foster, or is it an innate or inherited virtue that potential club brothers recognize in each other, a certain shared wisdom or set of values?"57 The aim of this essay was to show that it could be both: not only the personal ability and eligibility to become a club member, but also the result of a clubman's conforming to the requirements of club life and of his adopting the attitudes expected from him as a club member.

London clubs contributed to shape and reinforce the Englishman's cultural, social as well as national identity. The exploration of the concept of 'clubbability' enables us to reflect on the nature of sociability and masculinity, on the process of club affiliation, and more generally on the tensions generated by social interaction. Therefore, clubbability can be seen as a revolutionary phenomenon in eighteenth-century London, as a decisive change in social practices and sociability: it became a key to social prestige and political power and a visible sign of success. Interestingly, English club life and clubbability were not only exported to the whole British Empire, but they also stood the test of time, thriving in Victorian and Edwardian England and even enjoying

56. Marlow, 113 .

57. Black, 110. 
a renewed popularity among the fashionable London circles of today. By favouring the creation of selective circles and networks, clubbability has definitely played a crucial part in the evolution of modern sociability in Britain and abroad. Clubbability was, in the eighteenth century, a revolution in the way people interacted with each other, it definitely has some interesting legacy as far as today's socializing habits and social networks are concerned. 